GRZEGORZ GŁĄB

\title{
REŻYSERZY POWOŁANIA - KAROL WOJTYŁA NA SZKLANYM EKRANIE
}

Kamery filmowe i telewizyjne towarzyszyły Janowi Pawłowi II od jego pierwszego improwizowanego przemówienia $\mathrm{z}$ balkonu bazyliki watykańskiej w wieczór 16 października 1978 roku, aż do 8 kwietnia 2005 roku, kiedy podczas pogrzebowej Mszy Świętej celebrowanej przez kardynała Josepha Ratzingera wiatr wiejący nad placem Świętego Piotra zamknął znajdujący się na papieskiej trumnie ewangeliarz (zob. Garbicz i Lis 6). Utrwalały one zarówno oficjalne nauczanie - przekaz wiary i miłosierdzia - zwierzchnika Kościoła katolickiego, jak i słowa, gesty, emocje odsłaniające prywatny, a nawet intymny profil tej jednej z najbardziej szanowanych postaci naszych czasów. Dzięki nim ludzie wierzący - ale nie tylko - mogli poczuć się współuczestnikami papieskiego pielgrzymowania, bezpośrednimi odbiorcami głoszonego przez niego orędzia miłości i pokoju. Nade wszystko jednak mogli poznać człowieka, który odważnie i konsekwentnie mierzył się z problemami świata, próbując uczynić go lepszym.

Wśród wielu przejawów wyjątkowości pontyfikatu Jana Pawła II należy dostrzec także fakt, że był on pierwszym papieżem, który jeszcze za życia stał się pierwszoplanowym bohaterem kilku pełnometrażowych filmów fabularnych i przeszło stu obrazów dokumentalnych (zob. Luter 225). Jest to o tyle istotne, że - jak podają Adam Garbicz i ks. Marek Lis w monografii poświęconej filmowym portretom „polskiego” Ojca Świętego - przed wyborem Karola Wojtyły papieże trafiali na ekrany znacznie rzadziej i najczęściej byli sytuowani przez twórców na peryferiach

Ks. dr GrZeGorz GŁĄB - Katedra Literatury Współczesnej w Instytucie Literaturoznawstwa KUL; adres do korespondencji: Katolicki Uniwersytet Lubelski Jana Pawła II, Al. Racławickie 14, 20-950 Lublin; e-mail: gglab@kul.lublin.pl. ORCID: http://orcid.org/0000-0001-7155-0972. 
wydarzeń przedstawionych (zob. Garbicz i Lis 5) ${ }^{1}$. Wyjątkami od owej reguły są: fabularyzowana biografia św. Piusa X (Ludzie nie patrza w niebo, reż. Umberto Scarpelli, 1952), trzy ekranizacje życia i posługi Jana XXIII (I przyszedt człowiek, reż. Ermanno Olmi, 1965; Papież Jan, reż. Giorgio Capitani, 2002; Dobry Papiez, reż. Ricky Togmazzi, 2003) oraz filmowy obraz Jana Pawła I (Papież Luciani uśmiech Boga, reż. Giorgio Capitani, 2006).

Andrzej Luter podnosi zarzut, że „filmy o Janie Pawle II mają charakter ilustracyjny, pozbawione są metafizycznej głębi, a poza tym pełne są uproszczeń i to nie tylko tych historycznych i teologicznych, ale także psychologicznych" (231). Należy zgodzić się z przywołaną opinią publicysty, chociaż powinniśmy być dalecy od totalnego, całościowego deprecjonowania owych artystycznych wizji, mając na uwadze paletę pozytywnych uczuć i emocji, które za ich sprawą stały się udziałem szerokiego kręgu odbiorców. Ponadto - mimo dydaktycznej, moralizatorskiej i niepogłębionej formy - są to filmy w znacznej mierze ujawniające źródła duchowej siły Karola Wojtyły. Tym samym pozwalają one widzowi zrozumieć, w jaki sposób osobiste przeżycia z czasów dzieciństwa i młodości wpłynęły na ukształtowanie się postaw i poglądów przyszłego Papieża - „człowieka posłanego przez Boga do wypełnienia nadludzkiej misji i przygotowania świata na czekające go wielkie wydarzenia" (Socci 7). W tym kontekście motywem prymarnym wydaje się kwestia narodzin powołania, o którym ze względu na jego niezwykłość i pozaracjonalność w filmie mówić najtrudniej - łatwo bowiem wówczas popaść w banał i patos (zob. Luter 227).

Jan Paweł II, pisząc o genezie swojej szczególnej zażyłości ze Stwórcą, konstatował: „U początków... Tajemnica!” (Dar i Tajemnica 7). I wyjaśniał:

Historia ta znana jest przede wszystkim Bogu samemu. Każde powołanie kapłańskie w swej najgłębszej warstwie jest wielka tajemnica, jest darem, który nieskończenie przerasta człowieka. Każdy z nas kapłanów doświadcza tego bardzo wyraźnie w całym swoim życiu. Wobec wielkości tego daru czujemy, jak bardzo do niego nie dorastamy. (Dar i Tajemnica 7)

\footnotetext{
${ }^{1}$ Autorzy zauważają, że następcy świętego Piotra zazwyczaj byli postaciami drugoplanowymi w filmach religijnych i historycznych, jak choćby Innocenty III w ekranizacjach losów świętego Franciszka z Asyżu (m.in. Brat Stońce, Siostra Księżyc, reż. Franco Zeffirelli, 1972) czy Juliusz II w Udręce i ekstazie (reż. Carol Reed, 1965). W dziejach kina miało również miejsce przedstawianie papieży w sposób kontrowersyjny. Adam Garbicz i ks. Marek Lis wskazują w tym kontekście na Audiencję (reż. Marco Ferreri, 1971), w której została ukazana watykańska biurokracja i procedury de facto uniemożliwiające dostęp do Biskupa Rzymu - Pawła VI, Tylko Beatrycze (reż. Stefan Szlachtycz, 1975), gdzie Jan XXII jest głównie wyrafinowanym sternikiem potęgi finansowej Watykanu, Ojca chrzestnego III (reż. Francis Ford Coppola, 1990), w którym pojawia się sensacyjny wątek śmierci Jana Pawła I, czy dramat wojenny Amen (reż. Costa Gavras, 2004), ukazujący w niekorzystnym świetle postać Piusa XII - papież, chcąc za wszelką cenę powstrzymać komunizm, jest gotowy do współpracy z hitlerowcami.
} 
Twórcom obrazów kinowych o Papieżu z Wadowic udało się wybrnąć z pułapki ujęć uwznioślających, ukazując „Tajemnicę, która jest darem” jako rzeczywistość niepoznawalną. Ich wyobraźnia w tym względzie znalazła umocowanie w rozwiązaniach fabularnych o formule otwartej, charakteryzującej się niedopowiedzeniami i wnioskowaniem zaledwie sugerowanym. Taki kształt, projekt wątku powołania $\mathrm{z}$ jednej strony aktywizuje poznawcze aspiracje odbiorców, z drugiej jednak nie wykracza poza obszar zdarzeń weryfikowalnych historycznie i dokumentarnie.

Pierwszym z filmów fabularnych przybliżających postać Karola Wojtyły - Jana Pawła II była międzynarodowa współprodukcja $Z$ dalekiego kraju², zrealizowana wkrótce po konklawe przez uznanego polskiego reżysera - Krzysztofa Zanussiego (zob. Garbicz i Lis 9-11; Luter 225). Dzieło to zasługuje na osobne omówienie z kilku powodów. Po pierwsze - w dziejach kina jest to jedyny obraz filmowy o Papieżu z Polski autorstwa rodzimego twórcy, po drugie zaś - został on przeznaczony przede wszystkim dla widza zagranicznego, niewiele wiedzącego o kraju ,zza żelaznej kurtyny" (film zawiera historię burzliwych i często tragicznych dziejów naszej ojczyzny lat 1920-1980). Co wydaje się jednak najważniejsze, ponieważ odróżnia tę produkcję od innych obrazów o Janie Pawle II - Karol Wojtyła jako bohater opowieści, która ma formę niemal dokumentu fabularyzowanego, jest w filmie postacią drugoplanową, dyskretnie ustawioną $\mathrm{w}$ cieniu, a w wielu fragmentach wręcz nieobecną. Mimo to film został przyjęty w Polsce z uznaniem. Reżyser wykorzystał moment historyczny, jakim był wybuch „Solidarności”, i w atmosferze „wolności” tamtego czasu wypowiedział skrywane dotąd przez komunistyczną cenzurę prawdy o polskich dziejach. Na pozytywnej recepcji tej produkcji zaważył też niewątpliwie autorytet twórcy, którego artystyczne dokonania streszczano już wówczas w nieprecyzyjnym określeniu: kino autorskie (zob. Marczak). Warto przypomnieć, że pełnometrażowy debiut Zanussiego - Struktura kryształu (1969) - krytycy uznali za trzeci - po Pokoleniu (1954/55) Andrzeja Wajdy i Nożu w wodzie (1961/62) Romana Polańskiego - z najmocniejszych debiutów w powojennym kinie polskim (zob. Lubelski 10). Od momentu owej premiery reżyser stał się na szereg lat „ulubionym twórcą rodzimej publiczności inteligenckiej, której - jak twierdzi Tadeusz Lubelski - nikt wcześniej nie proponował tak poważnej rozmowy za pośrednictwem ekranu" (10). Krzysztof Zanussi ustanowił bowiem pewien wzór fabularny, który

${ }^{2}$ From a Far Country: Pope John Paul II, reżyseria: Krzysztof Zanussi; scenariusz: Jan Józef Szczepański, Andrzej Kijowski, Vincenzo Labella, Krzysztof Zanussi [projekt: Diego Fabbri]; zdjęcia: Sławomir Idziak; muzyka: Wojciech Kilar; obsada: Cezary Morawski (Karol Wojtyła), Sam Neill (Marian), Lisa Harrow (Wanda), Christopher Cazenove (Tadek), Warren Clarke (Władek), Maurice Denham (abp Adam Sapieha); produkcja: RAI/ITC/Transworld/Film Polski; Włochy/Wielka Brytania/ Polska, 1981; 139'. 
dla całego kanonu jego twórczości okazał się decydujący - konfrontacja dwóch postaci stanowiąca oś fabuły okazuje się jednocześnie zderzeniem dwóch postaw życiowych/światopoglądowych, co w konsekwencji prowokuje widza - poniekąd zmusza go - do zajęcia w tym sporze stanowiska.

Jednak zdaniem T. Lubelskiego niezależnie od fabularnego modelu pojedynku postaw, autora Iluminacji (1973) i Barw ochronnych (1976/77) „kusiła od początku strategia reżysera-mędrca, który stawia przed oczami odbiorcy wzór życia idealnego" (11). Opinia wybitnego historyka polskiej kinematografii wyjaśnia zatem powód, dla którego Zanussi zdecydował się na film o Janie Pawle II ${ }^{3}$. Jako przenikliwy artysta, zdawał on sobie wszakże sprawę, że bezkrytyczne propagowanie najszlachetniejszego nawet wzorca bywa w sztuce karkołomne i przeciwskuteczne (zob. Lubelski 11). Stąd, poszukując konstrukcyjnego zabiegu, który miałby na celu złagodzenie dydaktyzmu, Zanussi zrealizował pomysł - o czym już wspomniano - usunięcia głównej postaci z pierwszoplanowego nurtu zdarzeń na rzecz opowieści o mało w świecie znanym kraju, który go ukształtował.

Film otwierają obrazy thumów wiernych uczestniczących w 1926 roku w pasyjnych misteriach w Kalwarii Zebrzydowskiej. Wśród pielgrzymów, wraz ze swoim ojcem, znajduje się także sześcioletni Karol Wojtyła. Początkowe sceny $Z$ dalekiego kraju zasługują na szczególną uwagę ze względu na głębię i znaczenie konstytuujących je epizodów. Widz ma możliwość obserwowania - a nawet uczestniczenia - w paraliturgicznej celebracji Męki Pańskiej za sprawą medium, jakim jest kamera usytuowana na planie filmowym w taki sposób, że rejestruje ona owe wydarzenie religijne zarówno w perspektywie szerokiej, całościowej, jak i przybliża jednostkowe reakcje i zachowania trwających na modlitwie pątników. W pewnym momencie oko kamery zastyga w bezruchu na wizerunku Jezusa obecnym na chuście św. Weroniki. Po chwili w identyczny sposób skupia się na twarzy małego Lolka. Należy podkreślić, że statyczność tych pojedynczych ujęć jest wyłącznie iluzoryczna. Wprawdzie chociaż chłopiec nie wypowiada w tym miejscu żadnej kwestii, nie wykonuje także żadnego ruchu, to jednak nie ulega wątpliwości, że pod wpływem kontemplacji portretu Zbawiciela jego oblicze ulega przemianie - koncentrację, skupienie na twarzy Karola zastępuje coś na kształt błogości, zafascynowania, zauroczenia. Ta niema scena, w której ,grają” jedynie oczy chłopca zwiastuje/odsłania metaforycznie duchowe przeobrażenie się tej postaci. Wskazuje również na działanie nadprzyrodzonej siły, której opis przekracza możliwości narracji werbalnej

\footnotetext{
${ }^{3}$ Filmowymi opowieściami o ludziach maksymalnie spełnionych - oprócz $Z$ dalekiego kraju - są także dwie inne produkcje Zanussiego: Życie za życie (1990) o franciszkańskim męczenniku Maksymilianie Marii Kolbe i adaptacja dramatu Wojtyły Brat naszego Boga (1997) o życiu i dziele Adama Chmielowskiego - świętego Brata Alberta.
} 
i obrazowej. Oprócz techniki montażu i pantomimicznego aktorstwa, medytacyjny, pozazmysłowy i nieprzenikniony klimat tworzy tu także muzyka Wojciecha Kilara o silnie ilustracyjnym charakterze (malowniczej procesji przez ośnieżone pola i lasy towarzyszy potężna fanfara instrumentów dętych i perkusji z chorałowym motywem Bogurodzicy, przechodząca następnie w temat smyczkowy, który dzięki repetycyjności buduje od samego początku wyczuwalny silny, stały puls), będąca według Zanussiego „uosobieniem losu” (zob. Lubelski 10).

Wstępną część $Z$ dalekiego kraju kończy epizod stanowiący miniadaptację, transpozycję motywu biblijnego o pobycie dwunastoletniego Jezusa w świątyni (zob. Łk 2,41-52). Oto Karol wymyka się spod opieki ojca i podąża śladami odtwórcy roli Jezusa w kalwaryjskim misterium, którego identyfikuje z prawdziwym Mesjaszem. Zaniepokojony rodzic poszukuje syna i ostatecznie odnajduje go w grupie aktorów odpoczywających w barze po przedstawieniu.

W tekście natchnionym tłem wydarzenia opisanego przez świętego Łukasza jest największe święto żydowskie - Pascha, którego obchody trwały siedem dni. Na podstawie obowiązujących interpretacji przepisów Prawa (Pwt 16,1-17; Wj 23,14-17) w tych dniach w Jerozolimie powinni przebywać wszyscy mężczyźni powyżej trzynastego roku życia - w święcie mogły wziąć również udział kobiety i dzieci. Obecność tych ostatnich, zwłaszcza chłopców stojących na progu dorosłości, podyktowana była potrzebą stopniowego wprowadzania ich w świadome praktykowanie nakazów Prawa. Z tego powodu także dwunastoletni Jezus znalazł się wówczas w świętym mieście. W sensie teologicznym Święto Paschy - upamiętniające przejście Izraelitów do Ziemi Obiecanej - stanowiło zapowiedź „przejścia” Jezusa z tego świata do Ojca, które dokonało się na drzewie krzyża i dzięki któremu ludzkość została wyzwolona z niewoli grzechu i śmierci. Warto też odnotować, że to właśnie w tym miejscu Ewangelii według Świętego Łukasza znajduje się pierwsza wypowiedź Jezusa, przez którą ukazuje On swoją niepowtarzalną relację z Bogiem, nazywając Go swoim Ojcem.

W filmie Zanussiego mamy do czynienia $\mathrm{z}$ dość swobodną realizacją wątku ewangelicznego, można nawet stwierdzić - z jej wersją humorystyczną. Niemniej jednak warto wskazać, że sześcioletni Karol, podobnie jak dwunastoletni Jezus, przybywa do miejsca świętego (w dziele polskiego reżysera nie jest to Jerozolima, ale Kalwaria Zebrzydowska) przed najważniejszą uroczystością religijną w roku (Wielkanoc - Pascha). Obie postacie łączy również to, że ich wędrówka ma charakter pielgrzymki, w trakcie której zarówno bohater $Z$ dalekiego kraju, jak i nastoletni Mesjasz samodzielnie uwalniają się spod opieki rodziców. Następnie obaj przebywają w towarzystwie osób starszych, chociaż trzeba zaznaczyć, iż w przypadku Lolka nie są to przedstawiciele religijnych i intelektualnych elit społecznych (filmowy Wojtyła jest za młody, by o tym wiedzieć, a jego postrzeganie świata, ludzi 
i zdarzeń cechuje dosłowność, jednowymiarowość). Wspólny jest także kontekst duchowy i dydaktyczny ich pielgrzymki - „edukacja religijna wtajemniczająca w rzeczywistość nadprzyrodzoną" (w czasie trwania misterium pasyjnego ojciec Karola tłumaczy synowi sens i znaczenie poszczególnych stacji Męki Pańskiej, w tym śmierci i zmartwychwstania Chrystusa). Ponadto w filmie autora Iluminacji, analogicznie jak w Ewangelii według Świętego Łukasza, pierwsze słowa protagonisty padają $\mathrm{w}$ rozmowie $\mathrm{z}$ rozżalonym i zmartwionym rodzicem. Jednak o ile perykopę biblijną o pobycie Jezusa w świątyni jerozolimskiej kończy dialog Syna z Matką, który ujawnia Jego prawdziwą, Boską naturę (zob. Łk 2,49), o tyle pytanie, które zadaje ojcu mały Wojtyła, brzmi: „Tato, dlaczego Jezus pije piwo?”.

Nieoczekiwany finał sceny w Kalwarii Zebrzydowskiej niewątpliwie osłabia podniosły, patetyczny ton początkowych partii filmu - urealnia też w dużej mierze postać sześcioletniego Karola, przyszłego Jana Pawła II. Mimo to w twórczej wizji Zanussiego profil Lolka posiada wyraźny stygmat wyjątkowości, którego źródło lokuje artysta w sferze nadprzyrodzonej. W ten sposób reżyser zdaje się wyrażać pogląd, że powołanie Wojtyły do szczególnej służby Bogu - w tym przypadku do kapłaństwa - było w nim obecne już we wczesnym dzieciństwie. Powołanie to rozumiane jest jako wybraństwo i przeznaczenie - dar, który z woli Stwórcy i za sprawą życiowych doświadczeń Karola, uległ późniejszemu wyostrzeniu i oszlifowaniu, stając się fundamentem jego dorosłej, w pełni uświadomionej tożsamości.

Kolejne epizody filmu spajają archiwalne zdjęcia i głos narratora opowiadającego o Wojtyle, jego dorastaniu w Wadowicach, studiach polonistycznych w Krakowie i pasji aktorskiej, dramatycznych wydarzeniach z dziejów Polski (wybuch II wojny światowej i jej okrucieństwa), pracy Karola w Zakładach Chemicznych Solvay i nieszczęśliwym wypadku bohatera (potrącenie przez niemiecką ciężarówkę). Ostatnie z przywołanych zdarzeń wyklucza Wojtyłę z działalności w podziemnym teatrze, co skutkuje tym, że akcja filmu koncentruje się na wojennych losach kilkorga młodych aktorów: Wandy, jej brata Mariana oraz Tadka. W obrazie Zanussiego Karol jako bohater pierwszoplanowy pojawi się jeszcze w scenie rozmowy z głową Kościoła krakowskiego, arcybiskupem Adamem Sapiehą. Wymiana poglądów dotyczy w głównej mierze kwestii miejsca i roli młodych Polaków w rzeczywistości okupacyjnej, metod prowadzenia walki z najeźdźcą i spraw duchowych. Reżyser $Z$ dalekiego kraju odsłania przy tej okazji wewnętrzne rozterki Karola, który wyraża obawę, że jego wstąpienie do konspiracyjnego seminarium duchownego może być oceniane jako akt tchórzostwa. Odpowiedź dostojnika kościelnego ostatecznie rozwiewa wątpliwości Wojtyły-alumna. Arcybiskup Sapieha przekonuje, że najskuteczniejszym sposobem na pokonanie zła jest ,walka duchem i Słowem”, przy czym nie chodzi tu o słowo będące konstruktem wypowiedzi, budulcem sztuki (teatru), ale o Słowo Boże, które jest ,żywe i skuteczne, ostrzejsze od każdego obosiecznego miecza [...] które prze- 
nika aż do rozdzielenia duszy i ducha, stawów i szpiku, rozsądza myśli i zamiary serca [...] i żadne stworzenie nie ukryje się przed nim, gdyż wszystko jest odkryte i jawne oczom Tego, któremu musimy zdać sprawę" (Hbr 4,12-13).

W dalszej części filmu Zanussi mówi o Papieżu już wyłącznie poprzez historie życia jego przyjaciół z Teatru Rapsodycznego (zob. Garbicz i Lis 10; Luter 225). Marian trafia do Auschwitz, Tadek walczy w oddziałach partyzanckich. Po wojnie Marian, podobnie jak Karol, zostaje księdzem, Tadek pisarzem socrealistycznym, Wanda, ze względu na nową sytuację polityczną Polski, zrywa z grą w teatrze i wychodzi za Tadka, a Władek - odtwórca roli Jezusa w kalwaryjskim misterium - zostaje robotnikiem wierzącym w socjalistyczne obietnice i świetlaną przyszłość „najlepszego z ustrojów". Ich losy i postawy splatają się na szklanym ekranie z życiem Karola Wojtyły i powojenną historią: budową Nowej Huty, represjami ze strony władz, sytuacją Kościoła, rodzącym się oporem społecznym wobec pseudowolnościowej polityki państwa.

Andrzej Luter trafnie zauważył, że Cezary Morawski kreujący Jana Pawła II „pokazywany jest w dziele Zanussiego najczęściej z tyłu, albo z daleka” (225), niejako z ukrycia, dyskretnie. Owa strategia artystyczna ma swoje wythumaczenie - „reżyser nie chciał bowiem opowiadać życiorysu Wojtyły, od okresu wadowickiego począwszy, a na watykańskim wyborze kończąc" (Luter 225). Pragnął jedynie odsłonić przed widzami (spoza Polski) skomplikowane i tragiczne dzieje kraju, w którym przyszło dorastać przyszłemu zastępcy Chrystusa na ziemi - oddać ducha czasów, które go ukształtowały. I z tego punktu widzenia - jak twierdzi już przywołany publicysta $-Z$ dalekiego kraju jawi się jako ,jeden z najciekawszych i najoryginalniejszych filmów o papieżu znad Wisły" (Luter 225). Opinia A. Lutra może budzić kontrowersje, szczególnie w kontekście schematyczności tego paradokumentalnego obrazu, którego bohaterowie zostali wykreowani przez artystę kina jedynie w kolorach białym i czarnym - bez półcieni, jednowymiarowo. Jednak mimo owych mankamentów film Zanussiego jest wartościowy mocą zawartej w nim prawdy o Polsce i o Kościele polskim okresu II wojny światowej i reżimu komunistycznego - PRAWDY, która na początku lat osiemdziesiątych XX wieku była potrzebna nie tylko widzowi zagranicznemu, ale także - a może przede wszystkim - odbiorcom tej produkcji w Polsce.

Kolejne filmy o Karolu Wojtyle - Janie Pawle II łączy to, że następca Świętego Piotra został w nich przez twórców ustanowiony bohaterem pierwszoplanowym. Poza obrazem Herberta Wise'a Papież Jan Pawet II z 1984 roku4, przybliżają one zarówno

${ }^{4}$ Pope John Paul II, reżyseria: Herbert Wise; scenariusz: Christopher Knopf; zdjęcia: Tony Imi; muzyka: Wilfred Josephs; obsada: Albert Finney (Jan Paweł II), Michael Crompton (Karol Wojtyła jak młodzieniec), Alfred Burke (ojciec Karola Wojtyły), Ronald Pickup (Jan Tyranowski), Jonathan 
dzieciństwo, młodość i dojrzewanie w wierze przyszłego Papieża, jak i przebieg jego ponad dwudziestopięcioletniego pontyfikatu. Obecny w nich motyw powołania implikuje rozważania o charakterze egzystencjalnym, duchowym i teologicznym, a także ukazuje zdarzenia i postacie, które tworzyły najpierw „seminarium domowe" bohatera (okres wadowicki), a następnie kształtowały jego osobowość i świat wartości w pierwszych etapach dorosłości (okres krakowski). Burząc linearną strukturę narracji - w przeważającej części kinowych opowieści o Papieżu znad Wisły czas dzieciństwa i młodość Karola odsłaniają sceny o charakterze retrospektywnym, będące efektem „odpamiętywania” minionego przez Wojtyłę-kardynała i Wojtyłę-papieża - kreatorzy ekranowego świata przedstawionego wkraczają w przestrzeń historii, którą można metaforycznie zdefiniować jako „KSIĘGA GENEZIS”. Jej ramy wyznaczają miasta: Wadowice i Kraków - „miejsca początki”, „miejsca źródła”, „miejsca powołania”.

Podczas siódmej pielgrzymki do Polski - w czerwcu 1999 roku - Jan Paweł II, modląc się w rodzinnym mieście, konstatował: „Tu w ... Wadowicach wszystko się zaczęło. I życie się zaczęło, i szkoła się zaczęła, i studia się zaczęły, i teatr się zaczął, i kapłaństwo się zaczęło” (,Spotkanie z wiernymi - przemówienie; Wadowice, 16 czerwca 1999 roku" 247). Podążając tym tropem, nie sposób nie wspomnieć o człowieku, którego życie legło u podstaw duchowego i egzystencjalnego „stawania się” Lolka - było „poniekad antycypacja jego seminaryjnego przygotowania do kapłaństwa" (por. Dar i Tajemnica 21) - Karola Wojtyły-seniora. W książce Dar i Tajemnica Ojciec Święty wspominał:

Mogłem na co dzień obserwować jego życie, które było życiem surowym. Z zawodu był wojskowym, a kiedy owdowiał, stało się ono jeszcze bardziej życiem ciągłej modlitwy. Nieraz zdarzało mi się budzić w nocy i wtedy zastawałem mojego Ojca na kolanach, tak jak na kolanach widywałem go zawsze w kościele parafialnym. Nigdy nie mówiliśmy z sobą o powołaniu kapłańskim, ale ten przykład mojego Ojca byt jakimś pierwszym domowym seminarium. (22)

Śmierć Emilii z Kaczorowskich, a następnie pierworodnego syna Edmunda, wyostrzyły w rodzicu Karola zmysł wiary - potrzebę bezgranicznego zawierzenia Bogu losów swoich i syna. Jednocześnie owe tragiczne wydarzenia przyczyniły się do pogłębienia ojcowskiej samoświadomości byłego oficera - konieczności bycia dla Lolka troskliwym opiekunem, wychowawcą, przyjacielem i powiernikiem (zob. Accattoli 12-14). Ową ,posługę” - bo tak należy ocenić życie Karola Wojtyły-se-

Newth (abp Adam Sapieha), Nigel Hawthorne (kard. Stefan Wyszyński), Natalie Slater (Hanna Jastrun); produkcja: Taft; USA, 1984; 149'. Wydarzeniem, które zainspirowało Wise'a i Knopfa do nakręcenia filmu o losach Karola Wojtyły, był zamach na życie Jana Pawła II, dokonany 13 maja 1981 roku przez tureckiego terrorystę Mehmeta Alego Agçę. 
niora - realizował on w duchu pokory, skromności, a także w charakterystycznej dla jego swoistości (temperamentu) dyscyplinie. W wywiadzie udzielonym przez Jana Pawła II André Frossardowi czytamy: „Ojciec, który umiał sam od siebie wymagać, w pewnym sensie nie musiał już wymagać od syna. Patrząc na niego, nauczyłem się, że trzeba samemu sobie stawiać wymagania i przykładać się do spełnienia własnych obowiązków” (Frossard, ,Nie lękajcie się!”15).

Tożsamy portret Wojtyły-rodzica wykreowali w swoich filmach o Papieżu z Polski ich artystyczni projektodawcy. W imaginacji wspomnianego już Wise'a, ale także Giacoma Battiata ${ }^{5}$, Johna Kenta Harrisona ${ }^{6}$ i Jeffa Blecknera ${ }^{7}$, ojciec Karola to człowiek modlitwy, uduchowiony introwertyk, który w relacjach międzyludzkich wykazuje się daleko posuniętą powściągliwością w okazywaniu/odsłanianiu emocji czy też osobistych przemyśleń. Niewątpliwie czynnikiem upodabniającym owe kreacje jest również nadane bohaterowi przez twórców „,przyporządkowanie sceniczne” - miejsce quasi-protagonisty w przestrzeni wydarzeń fabularnych. W dziełach przywołanych reżyserów wychowawca i opiekun Lolka to postać wyłącznie drugoplanowa, nakreślona przez profesjonalistów kamery zaledwie kilkoma klatkami filmowych scen. Najczęściej widzimy w nich człowieka rozmawiającego z Bogiem - w pewnym sensie wyalienowanego z rzeczywistości - prostolinijnego w mowie i działaniu, przy czym należy podkreślić, że aktywność werbalna bohatera jest każdorazowo znikoma, podobnie jak jego udział w głównym nurcie opowiadanej historii. Tym samym Wojtyła-senior jawi się w tych obrazach jako postać marginalna - bohater przestrzeni zakulisowej. Nie zmienia to jednak faktu, że w omawianych produkcjach, będących przede wszystkim paradokumentalną rekonstrukcją zdarzeń minionych,

${ }^{5}$ Karol, un uomo diventato Papa, reżyseria: Giacomo Battiato; scenariusz: Giacomo Battiato; zdjęcia: Giovanni Mammolotti; muzyka: Enio Morricone; obsada: Piotr Adamczyk (Karol Wojtyła), Olgierd Łukaszewicz (ojciec Karola Wojtyły), Małgorzata Bela (Hania), Raoul Bova (ks. Tomasz Zaleski), Jerzy Schejbal (abp Adam Sapieha), Lech Mackiewicz (kard. Stefan Wyszyński), Piotr Różański (Jan Tyranowski), Matt Craven (Hans Frank); produkcja: Tadoue/Mediaset; Włochy, 2005; 186’.

${ }^{6}$ Pope John Paul II, reżyseria: John Kent Harrison; scenariusz: John Kent Harrison, Francesco Contaldo, Francesco Arlanch, Salvatore Basile; zdjęcia: Fabrizio Lucci; muzyka: Marco Frisina; obsada: Jon Voight (Jan Paweł II), Cary Elwes (Karol Wojtyła), James Cromwell (abp Adam Sapieha), Christopher Lee (kard. Stefan Wyszyński), Wenanty Nocul (abp Stanisław Dziwisz), Mikołaj Grabowski (kard. Joseph Ratzinger); produkcja: Rai/Lux Vide/Intereconomia/Quinta/CBS/Granada/Balmedia/ Projektor; USA/Włochy/Polska, 2005; 190'.

${ }^{7}$ Have No Fear. The Life of Pope John Paul II, reżyseria: Jeff Bleckner; scenariusz: Michael Hirst, Lorenzo Minoli, Judd Parkin; zdjęcia: Roberto Benvenuti; muzyka: Carlo Siliotto; obsada: Thomas Kretschmann (Karol Wojtyła/Jan Paweł II), Jasper Harris (Karol Wojtyła jako chłopiec), Ignas Survila (Karol Wojtyła jako dwunastolatek), Petar Goranov (ojciec Karola Wojtyły), Inga Salkauskaite (matka Karola Wojtyły), Paulius Ignatavičius (Edmund Wojtyła), Roland Oliver (abp Adam Sapieha), Bruno Ganz (kard. Stefan Wyszyński), John Albasiny (ks. Stanisław Dziwisz); produkcja: Five Mile River; USA, 2005; 83'. 
nawet epizodyczna obecność na ekranie ojca Karola ewokuje podprogowo istotną dla wymowy filmów problematykę egzystencjalną i antropologiczną, a także duchową i nadprzyrodzoną. Owe treści implikowane są w świecie przedstawionym przez reżyserów za pomocą rozsianych po fabule utworów scen modlitwy Wojtyłów, ich krótkich rozmów, wspólnego doświadczania przez bohaterów choroby, samotności i cierpienia.

O znaczeniu owej więzi wyrażającej się najczęściej w prostych słowach i gestach, Jan Paweł II opowiedział A. Frossardowi kilkadziesiąt lat po śmierci ojca, przypisując rodzicielowi pierwszą inspirację encykliki Dominum et vivificantem (1986).

W wieku dziesięciu, dwunastu lat byłem ministrantem, ale muszę wyznać, że niezbyt gorliwym [...]. Mój ojciec dostrzegłszy moje niezdyscyplinowanie, powiedział pewnego dnia: „Nie jesteś dobrym ministrantem. Nie modlisz się dosyć do Ducha Świętego. Powinieneś się modlić do Niego". I pokazał mi jakąś modlitwę. Była to ważna lekcja duchowa, trwalsza i silniejsza niż wszystkie, jakie mogłem wyciągnąć w następstwie lektury czy nauczania, które odebrałem. (Frossard, Portret Jana Pawła II 56)

Glosę do owego świadectwa odnajdujemy w książce Przekroczyć próg nadziei:

Ojciec dał mi książeczkę do nabożeństwa, w której była modlitwa do Ducha Świętego [...]. Wtedy po raz pierwszy zrozumiałem, co znaczą słowa Chrystusa do Samarytanki o prawdziwych czcicielach Boga, to znaczy tych, którzy czczą Go w Duchu i w Prawdzie (por. J 4,23).

Zasadnicza role odegraty tu stowa mojego ojca, bo one kazały mi być prawdziwym czcicielem Boga, kazały mi szukać przynależności do prawdziwych Jego czcicieli, to jest tych, którzy czczą Go w Duchu i w Prawdzie. Odnalazłem Kościół jako wspólnotę zbawienia. Odnalazłem w tym Kościele swoje miejsce i swoje powołanie [...]. Dostrzegłem, za jaką cenę zostaliśmy odkupieni. I to wszystko wprowadziło mnie jeszcze bardziej w tajemnicę Kościoła, który właśnie jako tajemnica ma wymiar niewidzialny. (115)

Luigi Accatoli wyraził opinię, że „,motywem podjęcia przez Karola decyzji [o kapłaństwie - dop. - GG] były dwa wstrząsające fakty: śmierć ojca i wojna” (24). Teza włoskiego badacza, oparta - co należy podkreślić - na wypowiedziach Jana Pawła II (zob. np. Dar i Tajemnica 34-35), nie podlega dyskusji. Jednak w tym kontekście ważna wydaje się odpowiedź na pytanie, które z wymienionych wydarzeń okazało się decydujące? A może ich czasoprzestrzenna równowaga przesądza o nierozerwalności owych doświadczeń?

Uprawniona wydaje się hipoteza, że autorzy filmów o Papieżu z Polski wskazali jednoznacznie na dramat wojny jako czynnik determinujący egzystencjalne wybory Wojtyły. Wprawdzie wątek odejścia człowieka najbliższego protagoniście został przez twórców kinowych ujęty w pełnych melodramatycznego napięcia scenach śmierci bądź pochówku ojca Karola - na szczególną uwagę zasługuje zwłaszcza stosowny epizod z filmu Battiata, ukazujący Karola rozpaczającego w strugach desz- 
czu na mogile rodzica (widz obserwuje tę scenę w długich, spowolnionych kadrach, usytuowany za sprawą kamery tuż za nagrobnym krzyżem). Pomimo tego jednak należy stwierdzić, że nie jest on punktem zwrotnym w filmowych przedstawieniach drogi Karola do kapłaństwa. W dziełach Wise’a, Battiata, Harrisona czy Blecknera (kameralnie zrealizowany film telewizyjny w reżyserii Blecknera jest jedynym obrazem fabularnym, w którym oprócz bliskiej relacji Karola z ojcem, została też ukazana silna więź emocjonalna małego Lolka z mamą i bratem Edmundem) śmierć Wojtyły-seniora jest zaledwie jednym z wielu wydarzeń kształtujących intelektualną i religijno-duchową świadomość Karola-syna, Karola-studenta, Karola-aktora, Karola-katolika. Kolejnymi składowymi procesu wzrastania młodego Wojtyły w powołaniu są traumatyczne doświadczenia czasu wojny. Ich dowartościowanie, wyeksponowanie przez twórców filmowych nie może jednak dziwić, zważywszy na słowa Papieża utrwalone na kartach Daru i Tajemnicy:

Czas ostatecznego dojrzewania mojego powołania kapłańskiego [...] łączy się z okresem drugiej wojny światowej, z okresem okupacji nazistowskiej [...]. Powołanie, które dojrzewa w takich okolicznościach, nabiera nowej wartości i znaczenia. Wobec szerzącego się zła i okropności wojny sens kapłaństwa i jego misja w świecie stawały się dla mnie nadzwyczaj przejrzyste i czytelne.

Na skutek wybuchu wojny zostałem oderwany od studiów i od środowiska uniwersyteckiego. Straciłem w tym czasie mojego Ojca, ostatniego człowieka z mojej najbliższej rodziny. Wszystko to stanowiło także w znaczeniu obiektywnym jakiś proces odrywania od poprzednich własnych zamierzeń, poniekąd wyrywania z gleby, na której dotychczas rosło moje człowieczeństwo.

Jednakże nie był to tylko proces negatywny. Równocześnie bowiem coraz bardziej jawiło się w mojej świadomości światło; Bóg chce, ażebym został kapłanem. Pewnego dnia zobaczyłem to bardzo wyraźnie: był to rodzaj jakiegoś wewnętrznego olśnienia. To olśnienie niosło w sobie radość i pewność innego powołania. I ta świadomość napełniła mnie jakimś wielkim wewnętrznym spokojem. (34-35)

Powołanie Karola Wojtyły dojrzewało w anormalnej, wojennej rzeczywistości, którą w omawianych produkcjach filmowych tworzą obrazy eksterminacji ludności żydowskiej, deportacji i zagłady polskiej inteligencji, likwidacji życia kulturalnego i naukowego. Owe tragiczne doświadczenia przyszły kapłan i głowa Kościoła powszechnego przeżywa jako element dialogu z Panem wszelkiego stworzenia, poszukując Jego oblicza, a tym samym własnego przeznaczenia i sensu rzeczy. Ten dramatyczny dialog, który rozdziera serce Karola, dokonuje się w okresie jego pracy w fabryce chemicznej, samodzielnych studiów filozoficznych i kultywowania miłości do języka ojczystego, dającego możliwość przedstawiania rzeczywistości w formie teatralnej ${ }^{8}$.

${ }^{8}$ Zdaniem Benedykta XVI lata wojny były najbardziej decydującym okresem formacji w życiu Wojtyły. Wtedy właśnie - według Josepha Ratzingera - ,powstał specyficzny rodzaj «filozofii», charakterystyczny dla Jana Pawła II. Była to myśl, która pozostawała w dialektycznym stosunku z konkretem, 
W filmie Battiata Karol. Człowiek, który zostat papieżem Hania - świadek wywózki wadowickich Żydów do Auschwitz - pyta Lolka: „Gdzie On jest? Gdzie jest Bóg? Dlaczego cierpią sprawiedliwi?”. Wobec takiego bezmiaru bólu i rzezi niewinnych ludzi Wojtyła dostrzega jałowość wszelkiego dyskursu intelektualnego, a jego emocje determinują odpowiedź: „Cierpienie sierot i wdów jest nieme, bezsilne. Wokół nas obłęd i śmierć". Mimo to w artystycznej wizji włoskiego reżysera słowa Karola nie odzwierciedlają braku jego zaufania do Stwórcy bądź kryzysu wiary. Przeciwnie stanowią werbalny komunikat dążenia przez przyszłego duchownego do zrozumienia sensu obecności „krzyża” w przestrzeni ludzkiego życia. Warto podkreślić, że ten wątek przewija się we wszystkich filmach o Papieżu.

W pewnym jednak momencie - jak słusznie zauważa A. Luter - „widz mógł się obawiać, że twórcy za główny motyw powołania uznają rzekomy pacyfizm Wojtyły" (227). Należy zgodzić się z badaczem, że kiedy w dziełach Harrisona i produkcji Battiata „młody Karol mówi, że przemoc rodzi przemoc, a na zło nie można odpowiadać złem, to zastanawiamy się, co te słowa mogły znaczyć w czasie okupacji hitlerowskiej” (Luter 227). Tym niemniej można wyrazić pogląd, że kreatorom filmowego świata przedstawionego udało się ostatecznie opowiedzieć o powołaniu Wojtyły bez uciekania się do narracji ukonstytuowanej przez banał i patos. Zadecydowało o tym przedstawienie duchowych poszukiwań i rozterek bohatera jako heroicznej walki o własną tożsamość - podmiotowość zrodzoną przez Boga i w Nim zakorzenioną bez anturażu kiczowatego melodramatyzmu i ckliwej pobożnościowej nadbudowy.

W filmie Harrisona przyszły ksiądz w czasie modlitwy pyta Boga: „Dlaczego każesz mi żyć? Jaki to ma sens? Pozwól mi zrozumieć rzeczywistość i odkryć drogę do świętości”. Scenę o tożsamej wymowie spotykamy także w utworze Blecknera, w którym bohater woła do nieba: „Dlaczego ja? Dlaczego oszczędziłeś mnie, a nie Krzysztofa?". Natomiast w dziele Battiata, zwracając się do księdza Tomasza Zaleskiego - swojego spowiednika i duchowego mentora - Karol mówi: „Czuję złość i chcę walczyć, ale przecież nie chcę zabijać”. W odpowiedzi słyszy słowa, które zaważą na jego dalszym losie - wyznaczą cel, do którego będzie dążył: „Tylko miłość może nas obronić przed piekłem".

Z przytoczonych wypowiedzi wyłania się figura człowieka oddanego Chrystusowi i pragnącego służyć każdemu, nawet wrogowi (zob. Luter 227). Zdaniem A. Lutra ,jest w tej postawie czysta ewangelia, tak jak u księdza Ziei, który w czasie wojny, mimo że był kapelanem podziemia, nie wziął broni do ręki, a w początkowej fazie

myśl oparta na wielkiej tradycji, ale wciąż poszukująca sprawdzenia w obecnej rzeczywistości. Była to myśl, która brała swój początek ze spojrzenia artystycznego, a jednocześnie przewodziła jej troska pasterska: kierowała się w stronę człowieka, aby wskazać mu drogę”. Benedykt XVI (Joseph Ratzinger). Jan Pawet II. Mój umitowany Poprzednik 19; zob. także Ratzinger. „Jan Paweł II” 12-14. 
okupacji zdarzało się, że spowiadał Niemców" (227). W czym zatem tkwi tajemnica powołania Karola Wojtyły? Ekranizacje biografii Papieża z Polski ukazują go jako tego, który w pewnej chwili zobaczył, że droga, która się przed nim otwiera jako możliwość (bycie kapłanem), ma sens. Pośród „proroków”, którzy w dramatycznych latach wojny ukazali młodemu Karolowi logikę Bożej miłości - udręczonego Jezusa, obarczonego grzechami ludzi, i Maryję jako drogę prowadzącą do Syna - byli krawiec-mistyk Jan Tyranowski oraz arcybiskup krakowski książę Adam Sapieha. Pierwszy z nich, człowiek niezwykle głębokiej duchowości - odpowiedzialny za formację młodzieży w ramach tzw. Żywego Różańca przy parafii pod wezwaniem Świętego Stanisława Kostki na Dębnikach w Krakowie - wprowadził Wojtyłę na trop wielkiej mistyki chrześcijańskiej, a zwłaszcza dzieł świętej Teresy i świętego Jana od Krzyża (zob. Dar i Tajemnica 24-25; Przekroczyć próg nadziei 115). Dzięki Tyranowskiemu - jak pisze Antonio Socci - ,aktor odkrył «słowo» o wiele potężniejsze i głębsze, zdolne poruszyć w duszy tajemnicze struny i otworzyć umysł na ... Wieczność" (48). W ujęciu kreatorów narracji filmowej duchowa i intelektualna formacja protagonisty u boku charyzmatycznego krawca-zelatora osiąga apogeum po śmierci ojca Karola. Jedną z najważniejszych scen w filmie Jan Pawet II Harrisona jest ta, w której Tyranowski tłumaczy samotnemu i pogrążonemu w żałobie Lolkowi wymowę najkrótszego zdania w Ewangelii - „Jezus zapłakał” (zob. J 11,35): „Jezus zapłakał. Zapłakał nad Łazarzem, bo go kochał. Przypominasz Karolu Jezusa, który płacze, bo kocha. Pamiętaj, że na krzyżu Jezus także odczuwał samotność. Nie powstrzymało Go to jednak przed objawieniem swojej miłości do ludzi”.

Egzegeza „krakowskiego mistyka” wzmacnia w Karolu pragnienie służenia innym - bycia z tymi, którzy tracą nadzieję i wiarę w moc dobra, sprawiedliwości, miłości. Jest to o tyle istotne, że, jak głosi Tyranowski w filmach Battiata i Wise’a uświadamiając zagubionego życiowo Karola, który w jakiś aktywny, skuteczny sposób chce się włączyć do walki z okupantem - „zło można zwyciężyć jedynie miłością, a nie bronią". Na marginesie należy dopowiedzieć, że w obu powyższych produkcjach kinowych postać Tyranowskiego wydaje się groteskowa, a twórcy nie poradzili sobie z kreacją tajemniczego krawca. W efekcie w filmie Battiata Karol. Człowiek, który zostat papieżem animator powołania Wojtyły jawi się niczym mityczny Wernyhora - pół mag, pół wieszcz, a w dziele Wise’a Papież Jan Pawet II wyglądem i zachowaniem przypomina tajnego agenta gestapo lub członka polskiej organizacji podziemnej.

Na tym tle postać arcybiskupa Sapiehy wyróżnia się zdecydowanie większą wiarygodnością. Poznajemy go jako wybitnego intelektualistę, niezłomnego strażnika ładu eklezjalnego, a także dobrego pasterza strzegącego swojej owczarni i gotowego oddać życie w jej obronie. Przyjmując Karola do konspiracyjnego seminarium duchownego (scena ta ma szczególny wymiar w filmach Harrisona i Battiata), Sapieha wypowiada 
słowa, które będą stanowić w przyszłości istotę pasterskiej posługi Wojtyły-księdza, Wojtyły-Jana Pawła II: „Z wrogami ojczyzny trzeba walczyć wiarą i rozumem, bo przemoc rodzi jedynie przemoc” (Jan Pawet II); „Boży sens życia jest ważniejszy niż samo życie" (Karol. Człowiek, który zostat papieżem). Konstatacje arcybiskupa Sapiehy dopełniają przedseminaryjną formację Karola i ostatecznie utwierdzają go w przekonaniu, że największym, prawdziwym i jedynym zwycięskim sposobem, by oprzeć się złu w jakiejkolwiek formie i w każdym czasie, jest trwanie przy Miłości, która stała się ciałem. W jednej z pierwszych scen filmu Karol. Papież, który pozostat człowiekiem (2006) Jan Paweł II przemawia do dostojników watykańskich. Wystąpienie głowy Kościoła katolickiego wieńczy konkluzja: „Zadaniem papieża jest dawać nadzieję, a ta rodzi się ze Słowa, które jest Miłością"9.

$\mathrm{Z}$ wymową motywu powołania w filmach o Janie Pawle II koresponduje liryczna wypowiedź Wojtyły z poematu Pieśń o Bogu ukrytym:

Miłość mi wszystko wyjaśniła, miłość wszystko rozwiązała dlatego uwielbiam tę Miłość, gdziekolwiek by przebywała (Pieśń o Bogu ukrytym 19)

Poetycka intuicja autora Brata naszego Boga to nic innego jak „laboratorium serca”, wyobraźni i umysłu (zob. Skwarnicki 5-10). Próba kontemplacji tajemnic, które dla kapłana-artysty były zawsze święte: Kościoła, powołania, Boga.

Ktoś się długo pochylał nade mną...

To nachylenie dobre, pełne chłodu zarazem i żaru, które się we mnie osuwa, a pozostaje nade mną, chociaż przemija opodal - lecz wtedy staje się wiarą i pełnią...

Zamknięty w takim uścisku - jakby muśnięcie po twarzy, po którym zapada zdziwienie i cisza, cisza bez słowa, która nic nie pojmuje, niczego nie równoważy w tej ciszy unoszę nad sobą nachylenie Boga

(Pieśń o Bogu ukrytym 19 i 20)

${ }^{9}$ Karol - Un Papa rimato uomo, reżyseria: Giacomo Battiato; scenariusz: Giacomo Battiato oraz Monica Zapelli, Gianmario Pagano, Gianfranco Svidercoschi; zdjęcia: Gianni Mammolotti; muzyka: Enio Morricone; obsada: Piotr Adamczyk (Jan Paweł II), Michele Placido (dr Buzzonetti), Dariusz Kwaśnik (ks. Stanisław Dziwisz), Małgorzata Bela (Hanna Tuszyńska), Adriana Asti (Matka Teresa), Alkis Zanis (Ali Agça), Leslie Hope (Julia Ritter); produkcja: Taodue/RTI/Capri; Włochy, 2006; 195'. 
Niewątpliwie twórczość poetycką Wojtyły można uznać za źródło do poznania fenomenu powołania - szlaku Nieskończonego do serca człowieka - aczkolwiek zawsze pozostanie to w pewnym stopniu zagadką.

Nie inaczej będzie w przypadku dzieł filmowych, których tematem jest życie i posługa Jana Pawła II. Przedstawienie historii człowieka, który zmienił oblicze Kościoła i świata, domagało się od każdego z twórców skupienia uwagi na przybliżeniu tych postaci i zdarzeń, które na przestrzeni lat niejako „stworzyły” Papieża znad Wisły - charyzmatycznego duszpasterza, piewcę miłosierdzia, świętego. Ów cel determinował też konieczność wniknięcia w sferę pojęć i przeżyć (cierpienie, miłość, powołanie), które definiowane najczęściej wspólnym kwantyfikatorem „tajemnica", nie podlegają racjonalnej analizie, a tym samym rzetelnej i obiektywnej weryfikacji. W konsekwencji filmy o Janie Pawle II to produkcje faktograficzne najczęściej paradokumentalne rekonstrukcje - zrealizowane w stylu amerykańskiego kina popularnego, odwołującego się w pierwszej kolejności do pozytywnych ludzkich emocji. Przyjęta przez reżyserów koncepcja artystyczna groziła spłyceniem tematu powołania i przedstawieniem owego motywu w tonacji sensacyjnej lub sentymentalnej. Na szczęście twórcy nie próbowali tej „tajemnicy” rozszyfrować do końca, dając widzowi jedynie możliwość poznania drogi, jaką Lolek, młody Karol Wojtyła, przebył do dorosłości, upodmiotowionej świadomości i Miłości. Dzięki temu powołanie oznacza w owych przedsięwzięciach artystycznych „wędrówkę” - wędrówkę do Boga, „który nachyla się nad człowiekiem”.

\section{BIBLIOGRAFIA}

Accattoli, Luigi. Karol Wojtyła. Człowiek końca tysiąclecia. Tłum. Grzegorz Niedźwiedź i Sławomir Klim, Wydawnictwo św. Antoniego, 1999.

Benedykt XVI (Joseph Ratzinger). Jan Paweł II. Mój umiłowany Poprzednik. Tłum. Robert Łobko, Edycja Świętego Pawła, 2007.

Frossard, André. „, Nie lękajcie się!’” Rozmowy z Janem Pawłem II. Tłum. Anna Turowiczowa, Libreria Editrice Vaticana, 1982.

Frossard, André. Portret Jana Pawła II. Tłum. Maria Tarnowska, Znak, 1990.

Garbicz, Adam, i Marek Lis. Filmowe portrety pontyfikatu. Jan Pawet II w 100 odstonach. Księgarnia św. Jacka, 2007.

Jan Paweł II. Przekroczyć próg nadziei. Jan Pawet II odpowiada na pytania Vittoria Messoriego. Redakcja Wydawnictw Katolickiego Uniwersytetu Lubelskiego, 1994.

Jan Paweł II. Dar i Tajemnica. W pięćdziesiąta rocznicę moich święceń kapłańskich. Wydawnictwo św. Stanisława BM, 1996.

Jan Paweł II. „Spotkanie z wiernymi - przemówienie (Wadowice, 16 czerwca 1999 roku)”. Jan Paweł II. Polska 1999 - przemówienia i homilie, red. Krzysztof Kuźnik, Katolicka Agencja Informacyjna i Wydawnictwo Michalineum, 1999, ss. 241-250.

Lubelski, Tadeusz. „Filmowiec dla poszukiwaczy sensu”. Kino, nr 9, 2019, ss. 9-14.

Luter, Andrzej. „Papież na ekranie”. Akcent, nr 3, 2018, ss. 225-231. 
Marczak, Mariola. Niepokój i tęsknota. Kino wobec wartości. O filmach Krzysztofa Zanussiego. Wydawnictwo Uniwersytetu Warmińsko-Mazurskiego, 2011.

Pismo Święte Starego i Nowego Testamentu. Najnowszy przektad z języków oryginalnych z komentarzem, oprac. Zespół Biblistów Polskich z inicjatywy Towarzystwa Świętego Pawła, Częstochowa, 2009.

Ratzinger, Joseph. „Jan Paweł II”. Joseph Ratzinger i Franciszek Macharski. Jan Pawet II. 20 lat w historii Kościoła i świata. Tłum. Paweł Soppa, Edycja Świętego Pawła, 1999, ss. 7-31.

Skwarnicki, Marek. „Słowo wstępne”. Jan Paweł II. Poezje i dramaty. Wybór i układ Marek Skwarnicki i Jerzy Turowicz, Znak, 1998, ss. 5-10.

Socci, Antonio. Tajemnice Jana Pawła II. Tłum. Jolanta Kornecka-Kaczmarczyk, Dom Wydawniczy Rafael, 2007.

Wojtyła, Karol. „Pieśń o Bogu ukrytym”. Karol Wojtyła. Poezje i dramaty. Wybór i układ Marek Skwarnicki i Jerzy Turowicz, Znak, 1998, ss. 17-34.

\section{REŻYSERZY POWOŁANIA - KAROL WOJTYŁA NA SZKLANYM EKRANIE}

Streszczenie

Filmy o Janie Pawle II kręcono już za jego życia. Zarówno w pełnometrażowych obrazach fabularnych, jak i w realizacjach dokumentalnych, będących swego rodzaju przewodnikami po najważniejszych wydarzeniach wielkiego pontyfikatu, twórcy starali się ukazać dzieje człowieka, który swoją posługą zmieniał oblicze świata - czynił go lepszym. W niniejszym artykule starano się poznać i przedstawić źródła duchowej mocy Wojtyły - opowiedzieć o jego „seminarium domowym” i o drodze, którą musiał przebyć, aby zostać kapłanem. Kreatorzy świata przedstawionego oparli swój przekaz na dokumentach archiwalnych, świadectwach osób z najbliższego otoczenia Papieża, a także na wspomnieniach Jana Pawła II. Korzystając z takiej bazy materiałowej, reżyserzy ukazali widzom wędrówkę Lolka/Karola do Boga, do jego niezwykłej z Nim zażyłości. Drogę, która była dla Papieża procesem otwierania się na Miłość - pielgrzymką do „sensu istnienia”.

Słowa kluczowe: Karol Wojtyła - Jan Paweł II; powołanie; kapłan; film

\section{DIRECTORS OF VOCATION - KAROL WOJTYŁA ON THE SILVER SCREEN}

\section{Sum mary}

Several films about John Paul II were shot during his lifetime. Both in feature films and documentary productions, which are a kind of guide to the most important events of the great pontificate, the film-makers tried to depict the history of a man who, through his service, transformed the face of the world by making it better. In this article, efforts are made to study and present the sources of Wojtyła's spiritual power - to talk about his 'home seminary' and the path he had to follow to become a priest. The creators of the worlds presented based their message on archival documents, the testimonies of those people closest to the Pope, as well as on the recollections of John Paul II. Based on such material, the directors showed the viewers the journey of Lolek/Karol towards God, towards his extraordinary intimacy with Him, a path which was, for the Pope, a process of opening himself up to Love - a pilgrimage to the 'sense of existence'.

Keywords: Karol Wojtyła - John Paul II; vocation; priest; movie 